\title{
Bacillus cereus KLUVAA Mediated Biocement Production Using Hard Water and Urea
}

\author{
V. Anitha, ${ }^{a}$ K. Abinaya, ${ }^{a}$ S. Prakash, ${ }^{a}$ A. Seshagiri Rao, ${ }^{b}$ and B. Vanavil ${ }^{a}$, \\ aDepartment of Biotechnology, Kalasalingam Academy of Research \\ and Education, Krishnankoil- 626 190, Tamilnadu, India \\ bepartment of Chemical Engineering, National Institute of Technology, \\ Warangal-506 004, Telangana, India
}

doi: 10.15255/CABEQ.2017.1096

Original scientific paper

Received: February 16, 2017

Accepted: May 10, 2018

In the present study, a potential bacterial strain with maximum urease activity was isolated from urea-rich paddy field soil for biocement production. The bacterial isolate was screened using Christensen selective agar media and named as KLUVAA. This isolate was found to be tolerant up to $10 \%$ urea. 16S rRNA sequencing analysis identified the isolate KLUVAA as Bacillus cereus. Biocement production was carried out using tap water with $431.7 \mathrm{mg} \mathrm{L}^{-1}$ of hardness as a natural source of calcium. Functional groups present in biocement were analysed using FT-IR spectrum. The morphology and elemental composition of the biocement was studied using SEM with EDS mapping and XRD analyses. Thermogravimetric analysis was used to study the thermal stability of the microbial biocement. Further, process parameters were optimized for enhancing the yield of biocement.

Key words:

Bacillus cereus, biocement, calcium carbonate, hard water, urease

\section{Introduction}

Biomineralization is a process of chemical modification of an environment using microbial activity that results in the precipitation of minerals. Three different mechanisms are involved in the production of biominerals: (1) Biologically controlled mineralization consists of cellular activities that specifically direct the formation of minerals. In this process, organisms control nucleation and growth of minerals, and are directly synthesized at a specific location within or on the cell, but only under certain conditions. (2) Biologically influenced mineralization is the process by which passive mineral precipitation is caused by the presence of cell surface organic matter, such as extracellular polymeric substances associated with biofilms. (3) Biologically induced mineralization is the chemical modification of an environment by biological activity resulting in supersaturation and the precipitation of minerals ${ }^{1}$.

Microbial induced calcite precipitation (MICP) involves precipitation of calcium carbonate due to microbial activity, and these deposits of calcium carbonate are known as biocement. Urease enzyme of the microbes induce the precipitation of calcium carbonate in systems rich in calcium ions. The hy-

"Corresponding author: B. Vanavil,

Email: vanavilbt@gmail.com; b.vanavil@klu.ac.in,

Phone: +91-4563 - 289042, Fax: +91-4563 - 289322 drolysis of urea by urease enzyme in ureolytic microorganism results in the formation of ammonia and carbamate $\left(\mathrm{H}_{2} \mathrm{CO}_{3}\right)^{2}$. Carbamate spontaneously decomposes to produce another molecule of ammonia and carbonic acid. The two ammonia molecules and carbonic acid subsequently equilibrate in water with their deprotonated and protonated forms, resulting in an increase in the $\mathrm{pH}$ that causes calcium to precipitate in the form of crystals ${ }^{2}$. Calcium carbonate precipitation is mainly governed by the following factors: (1) calcium concentration, (2) concentration of dissolved inorganic carbon (DIC), (3) $\mathrm{pH}$, and (4) availability of nucleation sites ${ }^{4}$. In addition, factors like bacteria type, bacterial concentration, temperature, and urea concentration are found to affect the efficiency of $\mathrm{MICP}^{1}$.

Four different groups of microorganisms are involved in the process: (i) Photosynthetic organisms - such as algae, (ii) Sulphate reducing bacteria responsible for dissimilatory reduction of sulphates, (iii) Organisms utilizing organic acids, and (iv) Organisms that are involved in the nitrogen cycle such as ammonification of amino acids/nitrate reduction/ hydrolysis of urea ${ }^{4,5}$.

Van Paassen et al. suggested that urea hydrolysis possesses the highest calcite conversion rate compared to other processes and hence most of the research on MICP is focused on urea hydrolysis ${ }^{6,7}$. Possible biochemical reactions in urea- $\mathrm{CaCl}_{2}$ medium to precipitate $\mathrm{CaCO}_{3}$ at the cell surface is given as follows 8 : 


$$
\begin{gathered}
\mathrm{Ca}^{2+}+\mathrm{Cell} \rightarrow \mathrm{Cell}-\mathrm{Ca}^{2+} \\
\mathrm{Cl}^{-}+\mathrm{HCO}^{3-}+\mathrm{NH}_{3} \rightarrow \mathrm{NH}_{4} \mathrm{Cl}+\mathrm{CO}_{3}^{2-} \\
\mathrm{Cell}-\mathrm{Ca}^{2+}+\mathrm{CO}_{3}^{2-} \rightarrow \mathrm{Cell}-\mathrm{CaCO}_{3}
\end{gathered}
$$

Different species of bacteria producing urease enzyme are used for calcite precipitation. They are Sporosarcina pasteurii (formerly Bacillus pasteurii), Bacillus sphaericus, Aerobacter aerogenes, $B$. megaterium, B. subtilis, Bacillus sp. CR2, B. thuringiensis, Deleya halophila, Halmonas eurihalina, Kocuria flava CR1, L. sphaericus CH5, Methylocystis parvum, Myxococcus xanthus, Proteus mirabilis, Pseudomonas denitrificans, Sporolactobacillus sp., Sporosarcina ginsengisoli, Bacillus pseudifirmus, Bacillus cophnii, Bacillus cereus, Shewanella and Microbacterium sp. Some pathogenic bacteria such as Helicobacter pylori, Proteus vulgaris, Staphylococcus aureus and Pseudomonas aeruginosa also produce urease and are involved in the formation of calcium carbonate crystals clinically known as "urinary stones" $1,8,9$.

Recently, biocement has attracted wide attention due to its advantages, i.e. its production requires less energy and relatively low temperatures, as well as releases less greenhouse gases making it eco-friendly. The potential applications of MICP are summarized below. Biocementation is a clean, sustainable, eco-friendly crack repair technique that has been considered for sand, ground improvement, and construction of low energy buildings. Biocementation can be applied for remediation of surface cracks and fissures in various structural formations, surface soil consolidation, and improvement of strength and durability of concrete, bricks ${ }^{8,10,11}$.

This biomineralization technology mediated by the ureolytic microorganisms facilitates bioremediation of heavy metals like copper, cadmium, chromium, lead, and arsenic from soil or water by immobilizing these toxic metals through precipitation or co-precipitation with $\mathrm{CaCO}_{3}$. Recovery of phosphorus from wastewater using MICP can solve the problem of eutrophication, and the recovered phosphorous could be potentially used as a fertilizer. Calcium present in water creates several operational problems - mainly scaling in pipelines, boilers, heat exchangers, and aerobic and anaerobic reactors. Hence, MICP technology can be applied in the removal of calcium from water. Ureolytic microorganisms promotes $\mathrm{CaCO}_{3}$ precipitation, which in turn stimulates co-precipitation of radionuclides, like strontium, by substitution of $\mathrm{Ca}^{2+}$ ion and formation of radionuclide carbonate minerals. In addition, poly-chlorinated biphenyls can be removed using these carbonate biomineralizing bacterial isolates ${ }^{1,8,12}$.
Global warming is a serious environmental issue, which is primarily caused by increasing concentrations of $\mathrm{CO}_{2}$ in the atmosphere. MICP could act as an effective solution for the sequestration of $\mathrm{CO}_{2}$ from the environment, in turn creating carbonate minerals such as calcite, magnesite, and dolomite $^{1,8}$.

Novel fluorescence property of G. thermoglucosidasius induced calcite crystals encourages its usage as filler in rubber and plastics, and fluorescent marker in western blotting and other biochemistry applications ${ }^{1,8}$. The possibility of using this biocement for biomedical applications is yet to be explored.

Although different calcium sources, like calcium lactate, acetate and calcium gluconate can be used for the induction of $\mathrm{CaCO}_{3}$ precipitation, calcium chloride is the best source for induction of calcite precipitation ${ }^{13}$. Cheng et al. have investigated the possibility of using seawater as a calcium source for biocementation as a cost-effective alternative that provides high potential for using it in prevention of coastal erosion ${ }^{14}$.

In the present study, an attempt was made to isolate a bacterial strain from urea-rich paddy field soil with potent urease activity. The objective was to remove hardness coupled with novel biomaterial production. Hence, this strain was used for biocement production using tap water with high degree of hardness (source of calcium ions) through urease-mediated precipitation of $\mathrm{CaCO}_{3}$.

\section{Materials and methods}

Chemicals and media used in this study were of analytical grade, purchased from Himedia laboratories (Mumbai, India).

\section{Isolation of urease-producing bacteria}

The bacterial strains were isolated from urearich paddy field soil sample collected from Thiruvengadam, Tamilnadu, India, using serial dilution technique in nutrient agar. From the nutrient agar, several bacterial strains were selected based on different colony morphology. The purification procedure of each bacterial isolate under investigation was carried out by the agar quadrant streak plate method. Slants of each pure culture were prepared and preserved at $4{ }^{\circ} \mathrm{C}$ for testing the urease activity.

\section{Screening of urease producer}

To isolate strains capable of producing urease, Christensen's agar medium was used as selective media ${ }^{15}$. Christensen's agar media $\left(\mathrm{g} \mathrm{L}^{-1}\right)$ consists of urea $-20 \mathrm{~g}$, peptone $-1.0 \mathrm{~g}, \mathrm{KH}_{2} \mathrm{PO}_{4}-2.0 \mathrm{~g}$, 
glucose $-1.0 \mathrm{~g}, \mathrm{NaCl}-5.0 \mathrm{~g}$, agar $-15.0 \mathrm{~g}$, and phenol red indicator $-0.012 \mathrm{~g}$. The $\mathrm{pH}$ of the media was adjusted to $6.8 \pm 0.2$. Since urea is unstable and breaks during autoclaving, it was filtered through $0.2 \mu \mathrm{m}$ filter and added separately. The isolates were streaked on the Christensen's agar slants and incubated at $37{ }^{\circ} \mathrm{C}$ for $48 \mathrm{~h}$. Urease-producing isolates were identified by change in colour of the media from yellow to pink. The hydrolysis of urea by urease of the bacterial isolate releases ammonia, resulting in alkaline $\mathrm{pH}$. Phenol red indicator turns pink at an alkaline $\mathrm{pH}$ causing the media to turn pink.

\section{Selection of potent urease producer}

To screen the strain with potential urease activity, urea tolerance test was done by addition $2 \%, 4$ $\%, 6 \%, 8 \%$ and $10 \%$ of urea to the Christensen's agar plates. These plates were spot inoculated with positive isolates (urease producer) and incubated at $37{ }^{\circ} \mathrm{C}$ for $48 \mathrm{~h}$. A positive isolate with large pink halo in the plates at high concentration of urea was used for further experiments.

\section{Identification of the potent urease producer}

The isolate tolerant to high concentrations of urea was named KLUVAA and identified using 16S rRNA sequencing analysis.

\section{Determination of water hardness by EDTA method}

Tap water sample from various places of Kalasalingam Academy of Research and Education, Krishnankoil, India, were collected and the hardness was determined by EDTA method using EBT indicator ${ }^{16}$. The water sample with high level of permanent hardness due to presence of calcium ions was chosen for production of biocement using the isolate KLUVAA.

\section{Preparation of bacterial inoculum}

The inoculum used for biocement production was prepared using Luria-Bertani media and urea broth. The isolate KLUVAA was inoculated in each media and incubated at $37^{\circ} \mathrm{C}, 150 \mathrm{rpm}$ for $24 \mathrm{~h}$.

\section{Production of biocement from tap water using KLUVAA}

To $500 \mathrm{~mL}$ of tap water sample, $100 \mathrm{~mL}$ of 10 $\%$ filtered urea and $100 \mathrm{~mL}$ of cell inoculum were added and incubated for one week at $37{ }^{\circ} \mathrm{C}$ with and without agitation. The experiment was also repeated with $100 \mathrm{~mL}$ culture supernatants as a source of urease for biocement production instead of cell inoculum. After incubation, the calcium carbonate deposits formed were recovered by centrifugation at $10,000 \mathrm{rpm}$ for $10 \mathrm{~min}$. Then, the biocement pellet was dried in hot air oven at $55^{\circ} \mathrm{C}$ for 6 hours. The yield of biocement in all cases was determined.

\section{Characterization of biocement}

The biocement produced was characterized using light microscopy, Fourier Transmission Infra-Red spectrometer (FT-IR), Scanning Electron Microscopy (SEM) equipped with Energy Dispersive Spectroscopy (EDS), and X- Ray Diffractometer (XRD) analyses. The biocement crystals were viewed using light microscope at $4 \mathrm{X}$ magnification. The FT-IR spectrum of the biocement was recorded in the wave number range of $4,000-400 \mathrm{~cm}^{-1}$ on a Shimadzu FT-IR spectrometer by $\mathrm{KBr}$ pellet method. The morphology of the biocement was analysed using SEM (Zeiss) and the elemental composition analysis was determined using EDS mapping. The crystal structure of biocement was resolved using XRD (Bruker D8) pattern. Thermal stability of the biocement was studied using Thermo Gravimetric Analyser (Perkin Elmer/TGA4000) by increasing the temperature from 40 to $995{ }^{\circ} \mathrm{C}$ with a heating rate of $20^{\circ} \mathrm{C} \mathrm{min}^{-1}$.

\section{Optimization of bioprocess parameters for enhanced biocement yield}

\section{Effect of inoculum incubation time}

To study the effect of inoculum incubation time, isolate KLUVAA was inoculated and incubated at $37^{\circ} \mathrm{C}, 150 \mathrm{rpm}$ for $24 \mathrm{~h}, 48 \mathrm{~h}, 72 \mathrm{~h}$, and $96 \mathrm{~h}$ in different flasks containing urea broth. The cellfree supernatant was recovered at every time interval and used as urease source for biocement production. To $500 \mathrm{~mL}$ of tap water sample, $100 \mathrm{~mL}$ of $10 \%$ filtered urea and $100 \mathrm{~mL}$ of each cell-free supernatant were added and incubated for one week at $37{ }^{\circ} \mathrm{C}$ without agitation in separate flasks. Biocement was recovered and yield was determined as described previously.

\section{Effect of hard water volume}

Effect of volume of hard water on biocement production was studied at different volumes, such as 250, 500, 750 and $1000 \mathrm{~mL}$, and the method was repeated as before with $100 \mathrm{~mL}$ of $10 \%$ filtered urea and $100 \mathrm{~mL}$ of cell-free supernatant (from $48 \mathrm{~h}$ KLUVAA culture), and the biocement yield was determined.

\section{Effect of supernatant volume}

As supernatant was used as source of urease, the effect of supernatant volume in biocement production was studied using 50, 100, 150 and $200 \mathrm{~mL}$ 
of cell-free supernatant (from $48 \mathrm{~h}$ KLUVAA culture and the biocement production was carried as before in different flasks using $500 \mathrm{~mL}$ tap water and $100 \mathrm{~mL}$ of $10 \%$ filtered urea. Biocement was recovered and yield was determined as described previously.

\section{Effect of urea volume}

Biocement production was carried out using varying volumes of urea $(50,100,150,200$ and 250 $\mathrm{mL}), 500 \mathrm{~mL}$ of tap water and $100 \mathrm{~mL}$ of cell-free supernatant. Biocement was recovered and yield was determined as described previously.

\section{Results and discussion}

\section{Screening and selection of potent urease producer}

Eleven strains were selected based on colony morphology, and screened for urease activity using Christensen's agar. Out of the 11 strains, 3 strains were found to be positive for urease test (Fig. 1). From the urea tolerance study, one strain was able to turn the Christensen's agar plate into completely pink within $24 \mathrm{~h}$ at all tested concentrations of urea. This isolate was designated as KLUVAA and used for biocement production.

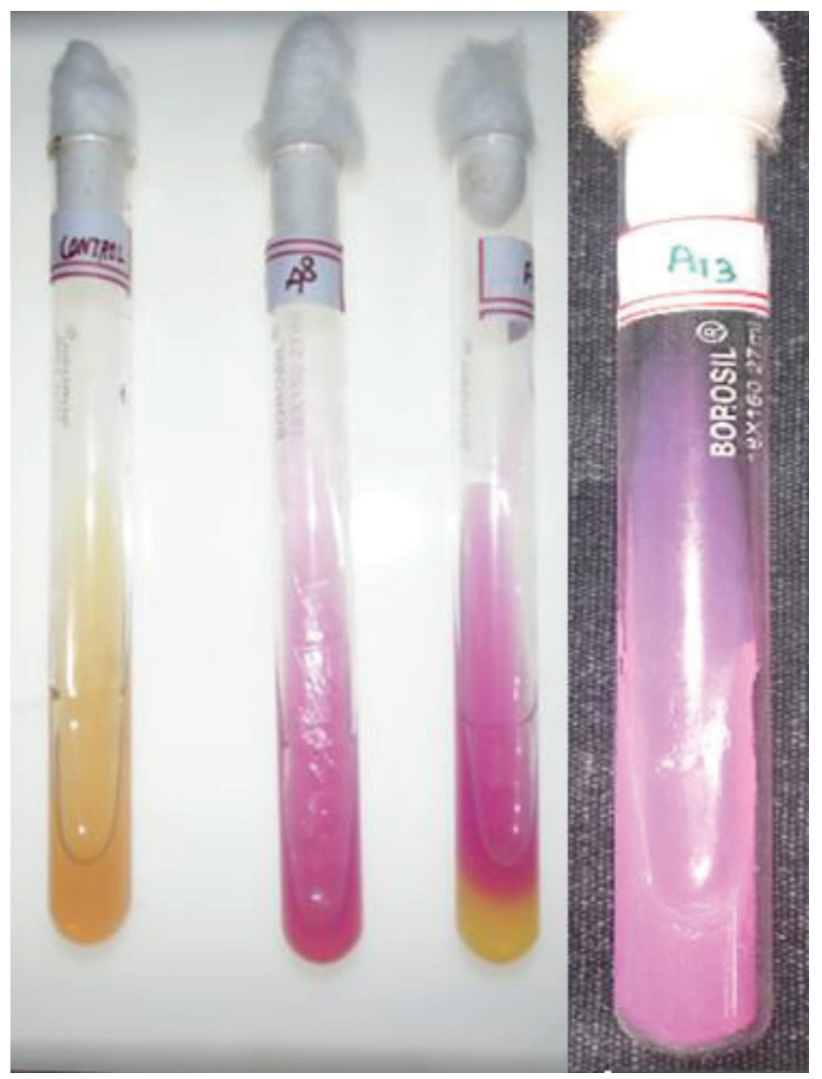

Fig. 1 - Screening of urease-producing bacteria using Christensen agar media

\section{Identification of the potent urease producer}

The isolate was found to be Gram positive, rod shaped bacteria using Gram staining. The $16 \mathrm{~S}$ rDNA sequence of KLUVAA was sequenced and deposited in the NCBI database under the GenBank accession number KX305955. BLASTN analysis of the $16 \mathrm{~S}$ rRNA sequence revealed that it was $100 \%$ identical to the $16 \mathrm{~S}$ rRNA sequence of Bacillus cereus. This is concurrent with earlier reports stating the use of $B$. cereus as a bioagent for biocement ${ }^{17,18}$.

\section{Determination of water hardness by EDTA method}

Tap water samples from four different places of Kalasalingam Academy of Research and Education, such as hostel, canteen, chemistry lab and biotechnology department were collected and analysed for hardness. From Table 1, it can be inferred that tap water from chemistry lab has high permanent hardness. Hence, chemistry lab tap water sample was used as calcium source for biocement production.

\section{Production of biocement from tap water using Bacillus cereus KLUVAA}

The yield of biocement was determined and presented in Table 2. As evident from the table, when supernatant from urea broth was used without agitation, the yield of biocement was found to be higher compared to other conditions. This is the first report stating the potential use of cell-free supernatant of Bacillus cereus as source of urease for

Table 1 - Determination of water hardness

\begin{tabular}{l|c|c|c}
\hline $\begin{array}{c}\text { Tap water } \\
\text { sample }\end{array}$ & $\begin{array}{c}\text { Total } \\
\text { hardness } \\
\mathrm{mg} \mathrm{L}^{-1}\end{array}$ & $\begin{array}{c}\text { Permanent } \\
\text { hardness } \\
\mathrm{mg} \mathrm{L}^{-1}\end{array}$ & $\begin{array}{c}\text { Temporary } \\
\text { hardness } \\
\mathrm{mg} \mathrm{L}^{-1}\end{array}$ \\
\hline Hostel & 599.77 & 420.08 & 179.69 \\
Canteen & 459.75 & 373.40 & 86.35 \\
Chemistry lab & 543.48 & 431.74 & 111.73 \\
Biotech Department & 534.67 & 411.29 & 123.37 \\
\hline
\end{tabular}

Table 2 -Production of biocement using B. cereus KLUVAA

\begin{tabular}{l|l|c|c}
\hline \multirow{2}{*}{$\begin{array}{c}\text { Media used } \\
\text { for } B \text {. cereus } \\
\text { KLUVAA }\end{array}$} & \multirow{2}{*}{$\begin{array}{c}\text { Urease } \\
\text { source }\end{array}$} & \multicolumn{2}{|c}{ Biocement yield g L ${ }^{-1}$} \\
\cline { 3 - 4 } & Cells & 0.4208 & 0.3364 \\
\hline \multirow{2}{*}{ LB } & With agitation & Without agitation \\
\hline \multirow{2}{*}{ Urea broth } & Cells & 0.1866 & 0.2722 \\
& Supernatant & 0.2132 & 0.1776 \\
\hline
\end{tabular}


production of biocement. Hence, the cell-free supernatant of urease producer can be employed for biocement production.

\section{Characterization of biocement produced by Bacillus cereus KLUVAA}

The crystalline appearance of the biocement was examined under a light microscope. The $4 \mathrm{X}$ magnification of biocement crystals are shown in Fig. 2. Needle-like crystals of biocement were observed. Fig. 3 and Table 3 show the FT-IR spectrum of biocement produced by Bacillus cereus KLUVAA and its signal assignment, respectively. The FT-IR analysis revealed the presence of carbonate and silicate in the biocement sample ${ }^{19}$. Fig. 4 shows the SEM image of the biocement. It was observed that the precipitated biocement structures were of different size and possessed fibre-like structures. The EDS mapping presented in Fig. 5 indicates the elemental composition of biocement. It is realized that calcium has predominant and intense peak, and other elements like $\mathrm{Si}, \mathrm{Fe}, \mathrm{Al}$ and Mo form a part of the biocement. Fig. 6 shows the XRD pattern of biocement crystals. Distinct diffraction peaks at $26^{\circ}$, $27^{\circ}, 33^{\circ}, 36^{\circ}, 38^{\circ}, 41^{\circ}, 43^{\circ}, 46^{\circ}, 48^{\circ}$ and $50^{\circ}$ confirmed the aragonite type of biocement crystals ${ }^{20}$. A sharp peak at $2 \theta=22^{\circ}$ in diffraction pattern indicates the presence of silicates in the biocement ${ }^{21,22}$. Different bacterial species induce different polymorphs of $\mathrm{CaCO}_{3}$ crystals. Reported studies have shown that biomineralization via bacteria-induced calcium carbonate precipitation results in the production of different phases of $\mathrm{CaCO}_{3}$. Calcium carbonate forms three anhydrous polymorphs: calcite, aragonite and vaterite; two hydrated crystalline
Table 3 -Characterization of biocement using FT-IR measurement

\begin{tabular}{l|l}
\hline $\begin{array}{c}\text { Peak } \\
\text { wavenumber } \\
\left(\mathrm{cm}^{-1}\right)\end{array}$ & \multicolumn{1}{c}{ Groups assignment } \\
\hline $1006.84,873.75$, & $\begin{array}{l}\text { Corresponding to internal modes of } \\
\text { carbonate ion in biocement }\end{array}$ \\
$1435.04,759.95$ & $\begin{array}{l}\text { Attributed to asymmetric stretching } \\
\text { vibration }(v 3) \text { of carbonate }\end{array}$ \\
1435.04 & $\begin{array}{l}\text { Out of plane bending vibration of the } \\
\text { carbonate }\end{array}$ \\
460.99 & $\begin{array}{l}\text { In plane }(v 2) \text { bending vibration of } \\
\text { silicate }\end{array}$ \\
\hline
\end{tabular}

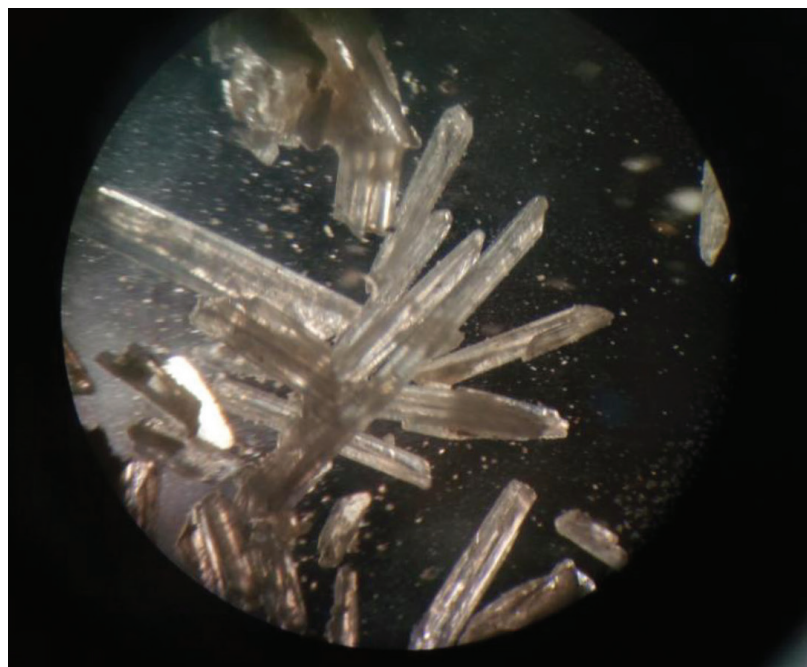

Fig. 2 - Microscopic observation of crystals of biocement from Bacillus cereus KLUVAA (4X magnification)

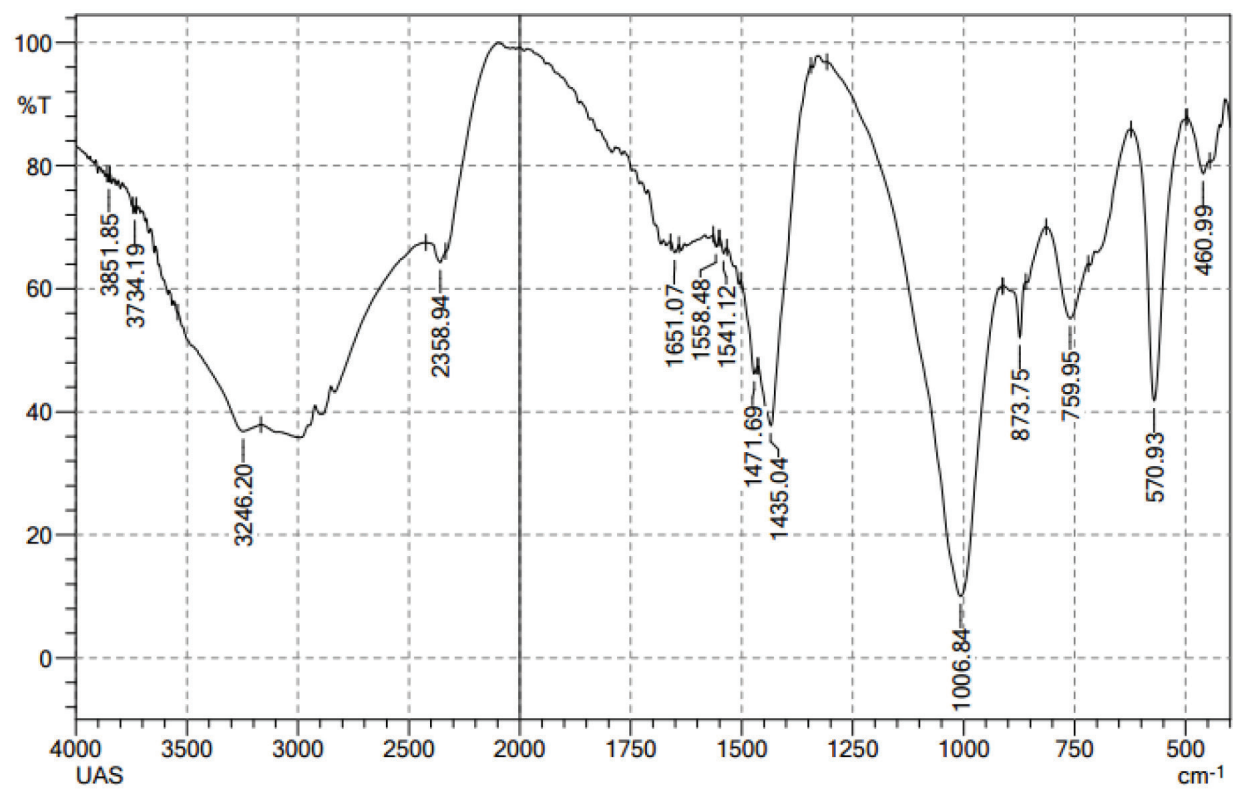

Fig. 3 - FT-IR spectrum of biocement produced by Bacillus cereus KLUVAA 


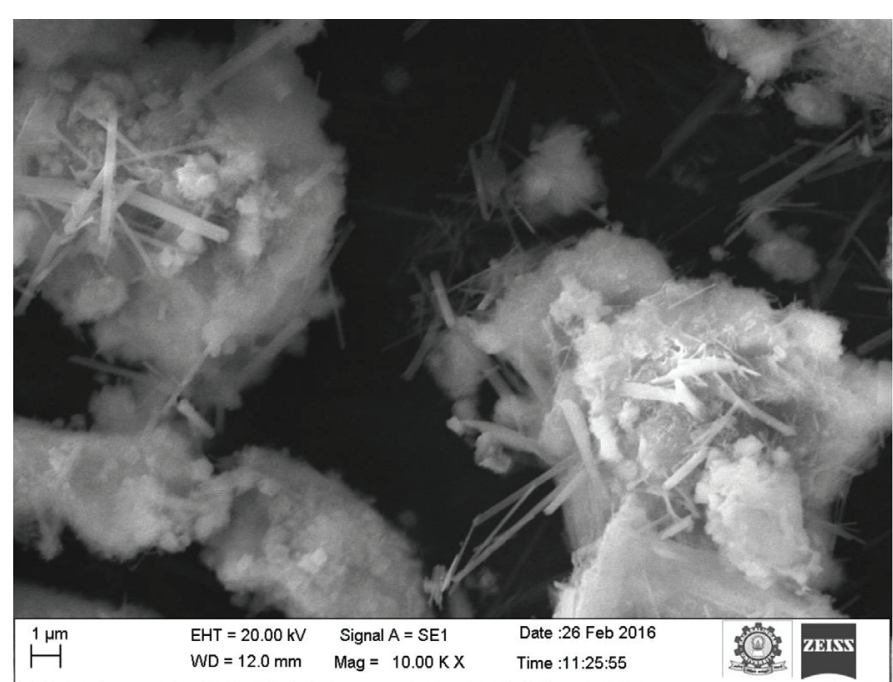

Fig. 4 - Characterization of biocement using SEM

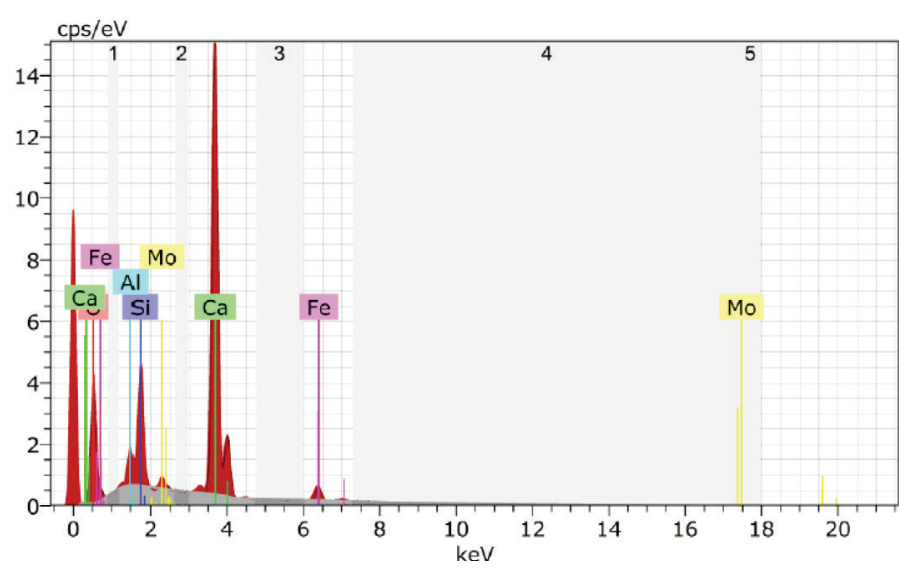

Fig. 5 - EDS mapping of biocement produced by B. cereus KLUVAA phases: monohydrocalcite $\left(\mathrm{CaCO}_{3} \cdot \mathrm{H}_{2} \mathrm{O}\right)$ and hexahydrocalcite and ikaite $\left(\mathrm{CaCO}_{3} \cdot 6 \mathrm{H}_{2} \mathrm{O}\right)$, and amorphous carbonate $(\mathrm{ACC})^{8}$. Calcite and vaterite are the most common among all polymorphs. Vaterite is a minor, metastable and transitional phase during calcite formation, while calcite is the most thermodynamically stable polymorph of $\mathrm{CaCO}_{3}$. Chen et al. found that $\mathrm{CaCO}_{3}$ produced by Proteus mirabilis has an unusual morphology and structure, consisting of vaterite hollow spheres ${ }^{1,23}$. In contrast, the present study reports formation of aragonite type of $\mathrm{CaCO}_{3}$ crystals in agreement with Rivadeneyra et al. where aragonite is the predominant crystal formed by Deleya halophila ${ }^{24}$.

Different sources of calcium induce crystals of different shapes. When calcium chloride is used, rhombohedral shape is induced which is characteristic of the most stable form of $\mathrm{CaCO}_{3}$ (calcite). With calcium acetate, a lettuce-like or lamellar shape, (a metastable form of $\mathrm{CaCO}_{3}$ ) composed of vaterite is induced, while calcium lactate and calcium gluconate induce a more complex form that leads to growth of vaterite with a spherical shape packing. These morphological differences in the crystal formation might be due to strain, differences in urease activity, exopolysaccharides produced by different bacteria that controls selection of calcite and culture media composition of the growth ${ }^{1}$. Hammes et al. showed that strains of Bacillus sphaericus induce rhombohedral calcite, hexagonal vaterite type of crystals ${ }^{25}$.

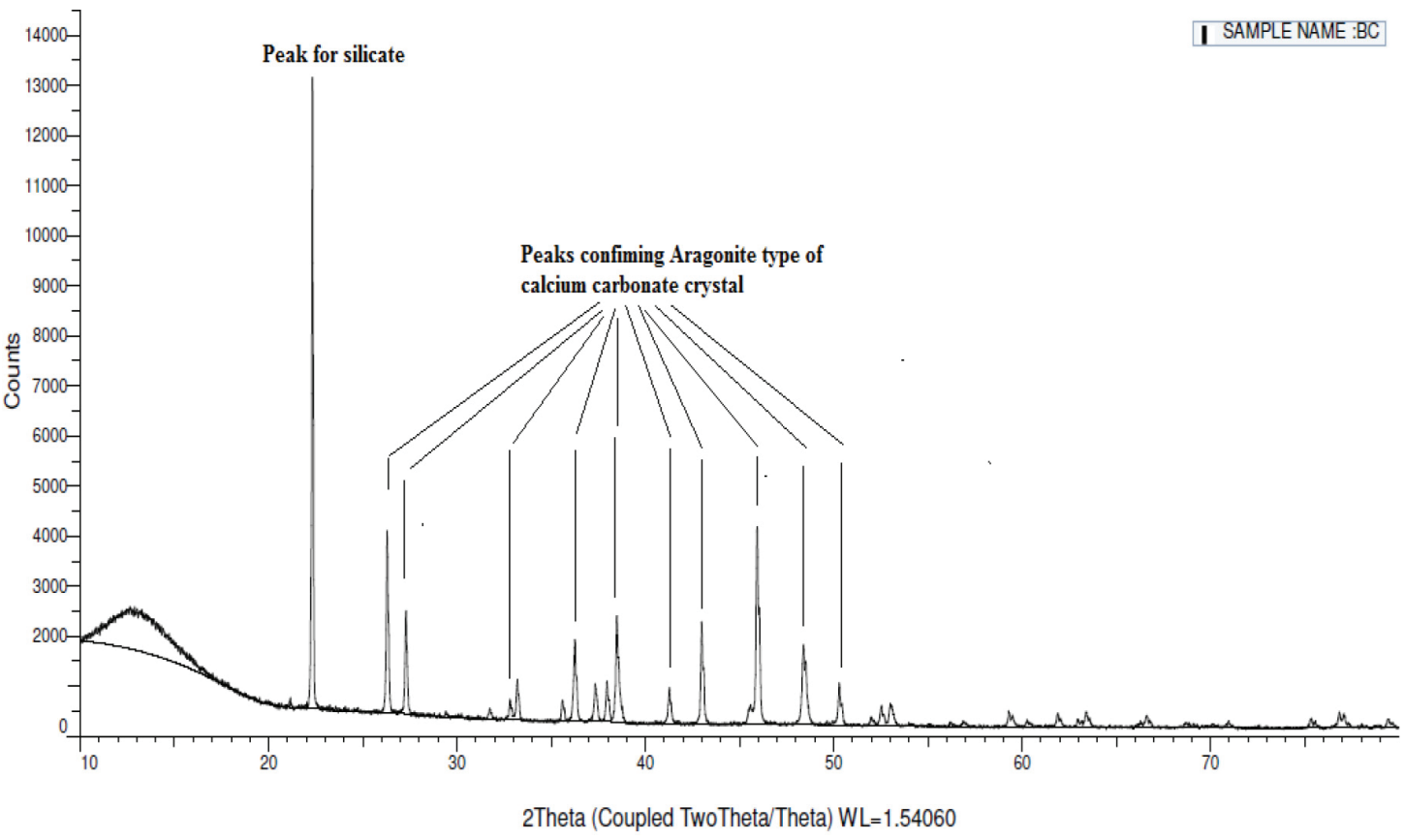

Fig. 6 - Analysis of biocement crystal structure using XRD 


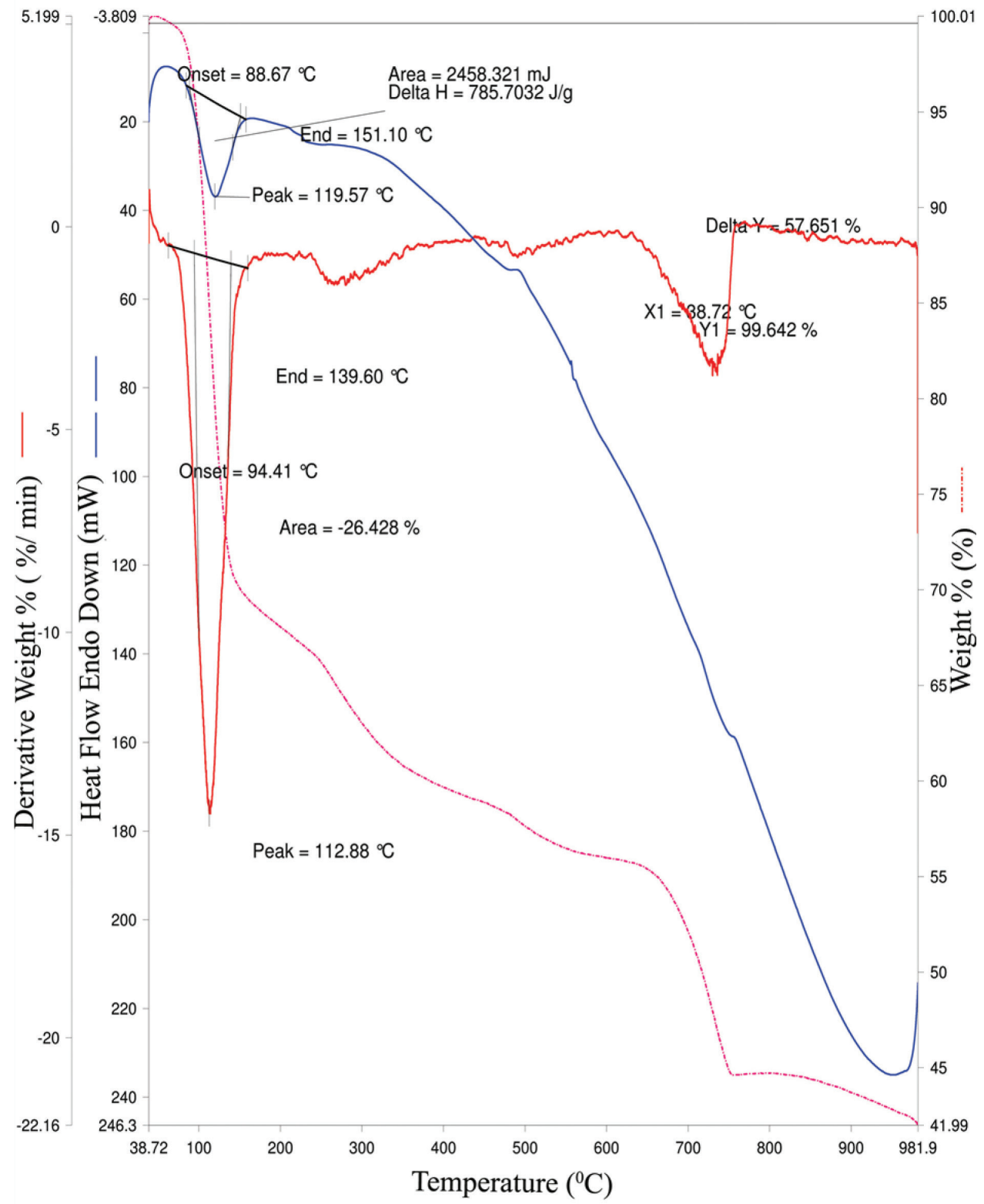

Fig. 7 - Thermogravimetric analysis of biocement

The precipitates in biocement were also confirmed to be calcium carbonate by TGA analysis. As observed from TGA curve (Fig. 7), the weight or mass loss between 38 and $140.5{ }^{\circ} \mathrm{C}$ is due to the dehydration of absorbed water. The weight percentage reduced to $45 \%$ by $750{ }^{\circ} \mathrm{C}$ due to calcite decarbonation $^{26}$.

\section{Determination of hardness of water after biocement production}

The hardness of the water sample was determined again after the biocement production. The hardness was found to be reduced from 431.74 $\mathrm{mg} \mathrm{L}^{-1}$ to $25.49 \mathrm{mg} \mathrm{L}^{-1}$ due to $\mathrm{CaCO}_{3}$ precipitation. In this way, this method can be used to remove water hardness coupled with biocement production.

\section{Optimization of bioprocess parameters for enhanced biocement yield}

The effect of various bioprocess parameters on biocement production were studied. From Fig. 8, it was observed that supernatant from a $48 \mathrm{~h}$ culture served as a suitable urease source for higher biocement yield compared to other inoculum ages. Among the tested volumes of hard water, production using $500 \mathrm{~mL}$ hard water provided increased deposition of biocement crystals (Fig. 9). Fig. 10 suggested that $100 \mathrm{~mL}$ of supernatant yields higher biocement. $100 \mathrm{~mL}$ of $10 \%$ urea was found to produce better biocement compared to others using $B$. cereus KLUVAA, as inferred from Fig. 11. Table 4 compares the amount of biocement precipitated from various studies. 


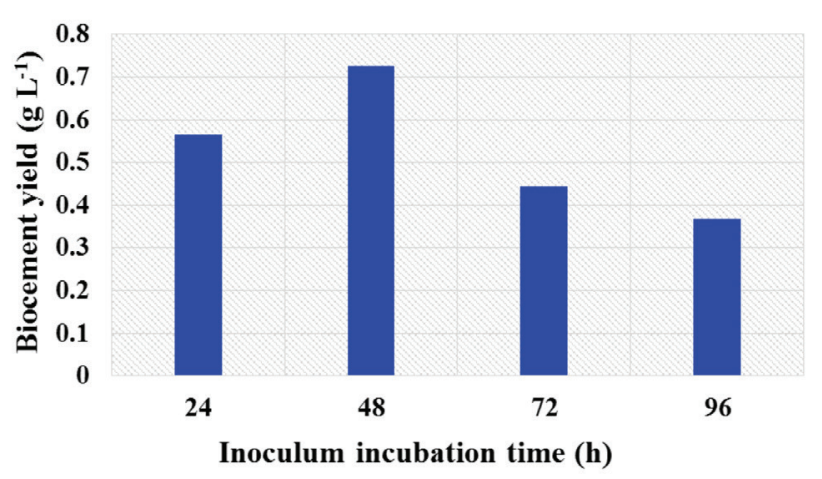

Fig. 8 - Effect of inoculum age on biocement production

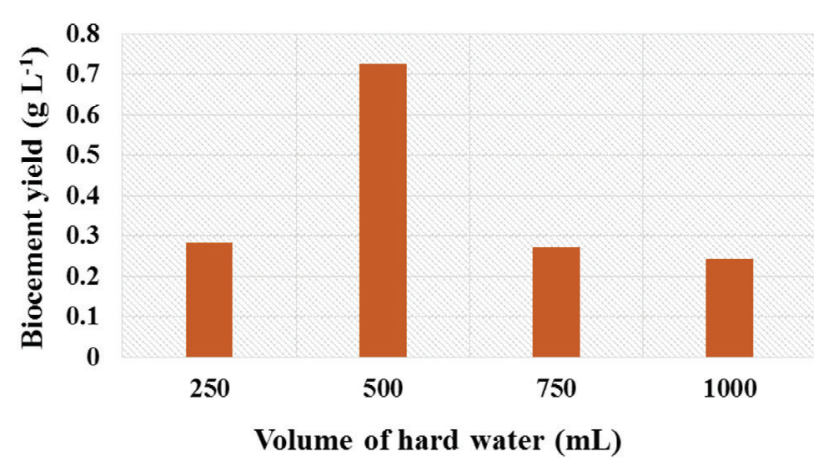

Fig. 9 - Effect of hard water volume on biocement production

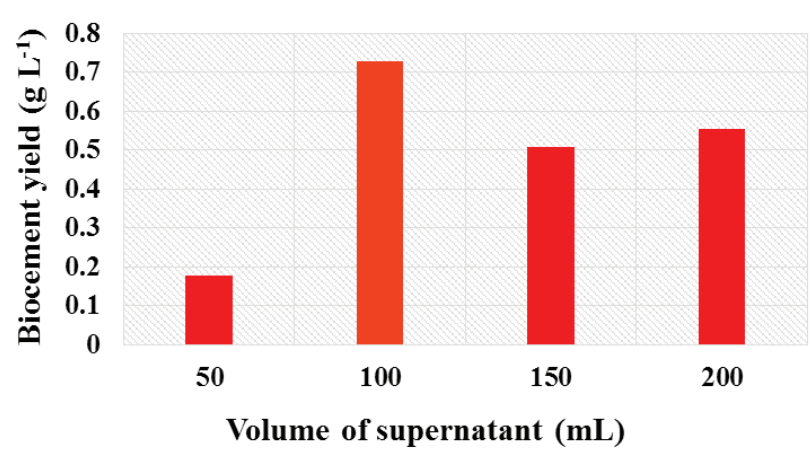

Fig. 10 - Effect of supernatant volume on biocement production

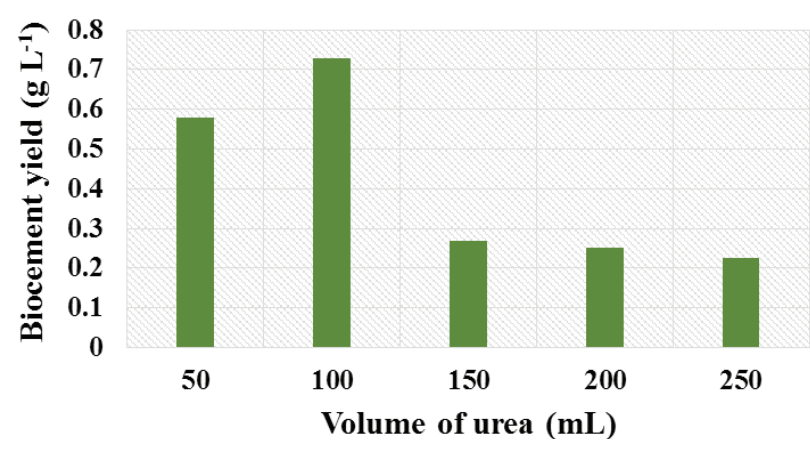

Fig. 11 - Effect of urea volume on biocement production
Table 4 -Urease-producing bacteria from various sources and amount of calcite precipitation

\begin{tabular}{|c|c|c|c|}
\hline Bacteria & Isolation site & $\begin{array}{c}\mathrm{CaCO}_{3} \\
\text { precipitation }\end{array}$ & References \\
\hline $\begin{array}{l}\text { Bacillus sp. } \\
\text { CR2 }\end{array}$ & $\begin{array}{l}\text { Mine tailing } \\
\text { soil Urumqi, } \\
\text { China }\end{array}$ & $\begin{array}{c}2.32 \mathrm{mg} / \text { cell mass } \\
(\mathrm{mg})\end{array}$ & 13 \\
\hline $\begin{array}{l}\text { L. sphaericus } \\
\text { CH5 }\end{array}$ & $\begin{array}{l}\text { Abandoned } \\
\text { expressway } \\
\text { and } \\
\text { abandoned } \\
\text { mining sites, } \\
\text { Gangwondo, } \\
\text { Korea }\end{array}$ & $980 \mathrm{mg} / 100 \mathrm{~mL}$ & 27 \\
\hline $\begin{array}{l}\text { B. megaterium } \\
\text { SS3 }\end{array}$ & $\begin{array}{l}\text { Calcareous } \\
\text { soil, Andhra } \\
\text { Pradesh, India }\end{array}$ & $187 \mathrm{mg} / 100 \mathrm{~mL}$ & 28,29 \\
\hline B. thuringiensis & $\begin{array}{l}\text { Calcareous } \\
\text { soil, Andhra } \\
\text { Pradesh, India }\end{array}$ & $167 \mathrm{mg} / 100 \mathrm{~mL}$ & 28 \\
\hline $\begin{array}{l}\text { B. cereus } \\
\text { KLUVAA }\end{array}$ & $\begin{array}{l}\text { Urea-rich } \\
\text { paddy field, } \\
\text { Tamilnadu, } \\
\text { India }\end{array}$ & $0.5638 \mathrm{~g} \mathrm{~L}^{-1}$ & This study \\
\hline
\end{tabular}

\section{Conclusion}

Around the world, several researchers are now focusing on harnessing the potential technical applications of these biominerals in various fields, ranging from biotechnology, geotechnology, paleobiology to civil engineering. The use of bacteria-induced carbonate biominerals is becoming increasingly popular day by day. From removal of heavy metals and radionuclides, removal of calcium from wastewater and biodegradation of pollutants, atmospheric $\mathrm{CO}_{2}$ sequestration, remediation of building materials, modifying the properties of soil and filler in rubber and plastics to fluorescent markers in stationery ink, bacterial carbonates find application in numerous fields.

In the present study, urea-rich paddy soil was screened for potential urease-producing bacterium with application for biocement production. Using $16 \mathrm{~S}$ rRNA sequencing, the screened isolate was identified to be $B$. cereus. The possibility of producing biocement using tap water and urea using this isolate was investigated. This work also reports the usage of cell-free supernatant from $B$. cereus KLUVAA as a source of urease for maximum production of biocement for the first time. The biocement was also characterized using FT-IR spectroscopy, SEM with EDS, XRD and TGA analyses. Further, the bioprocess parameters were optimized for improved biocement production using $B$. cereus KLUVAA. Our future work focusses on usage of urine- and 
urea-rich effluent as a source of urea for biocement production, and long-term efficacy of these biominerals needs further investigation.

\section{ACKNOWLEDGMENT}

The authors acknowledge the support provided by International Research Centre, Kalasalingam Academy of Research and Education, Krishnankoil for material characterization facilities like FT-IR, SEM-EDX and XRD.

\section{Nomenclature}

$\begin{array}{ll}\text { MICCP } & - \text { Microbially Induced Calcium Carbonate } \\ & \text { Precipitation } \\ \text { FT-IR } & - \text { Fourier Transform Infra-Red spectrum } \\ \text { SEM } & - \text { Scanning Electron Microscopy } \\ \text { EDS } & - \text { Energy Dispersive Spectroscopy } \\ \text { XRD } & - \text { X- Ray Diffractometer } \\ \text { DIC } & - \text { Dissolved Inorganic Carbon } \\ \text { EDTA } & - \text { Ethylene Diamine Tetra Acetic Acid } \\ \text { EBT } & - \text { Eriochrome Black T } \\ \text { BLASTN } \quad-\text { Nucleotide Basic Local Alignment Search } & \end{array}$

\section{References}

1. Anbu, P., Kang, C. H., Shin, Y. J., So., J. S., Formations of calcium carbonate minerals by bacteria and its multiple applications, Springer Plus. 5 (2016) 250. doi: https://doi.org/10.1186/s40064-016-1869-2

2. Ariyanti, D., Handayani, N. A., Hadiyanto, H., An overview of biocement production from microalgae, Internat. J. of Sci. and Eng. 2 (2011) 30.

3. Mobley, H. L., Hausinger, R. P., Microbial ureases: Significance, regulation and molecular characterisation, Microbiol. Rev. 53 (1989) 85.

4. Hammes, F., Verstraete, W., Key roles of $\mathrm{pH}$ and calcium metabolism in microbial carbonate precipitation, Rev. Environ. Sci. Biotechnol. 1 (2002) 3. doi: https://doi.org/10.1023/A:1015135629155

5. Stocks-Fischer, S., Galinat, J. K., Bang, S. S., Microbiological precipitation of $\mathrm{CaCO}_{3}$, Soil Biol. Biochem. 31 (1999) 1563. doi: https://doi.org/10.1016/S0038-0717(99)00082-6

6. van Paassen, L. A., Daza, C. M., Staal, M., Sorokin, D. Y., van der Zon, W., van Loosdrecht, M. C. M., Potential soil reinforcement by biological denitrification, Ecol. Eng. 36 (2010) 168. doi: https://doi.org/10.1016/j.ecoleng.2009.03.026

7. Gat, D., Tsesarsky, M., Shamir, D., Ronen, Z., Accelerated microbial-induced $\mathrm{CaCO}_{3}$ precipitation in a defined coculture of ureolytic and non-ureolytic bacteria, Biogeosciences 11 (2014) 2561. doi: https://doi.org/10.5194/bg-11-2561-2014

8. Dhami, N. K., Reddy, M. S., Mukherjee, A., Biomineralization of calcium carbonates and their engineered applications: A review, Front. Microbiol. 4 (2013) 314. doi: https://doi.org/10.3389/fmicb.2013.00314
9. Xu, G., Li, D., Jiao, B., Li, D., Yin, Y., Lun, L., Zhao, Z., $L i, S$., Biomineralization of a calcifying ureolytic bacterium Microbacterium sp. GM-1, Electronic Journal of Biotechnology 25 (2017) 21.

doi: https://doi.org/10.1016/j.ejbt.2016.10.008

10. Abo-El-Enein, S. A., Ali, A. H., Talkhan, F. N., Abdel-Gaw$\mathrm{wad}, H$. A., Utilization of microbial induced calcite precipitation for sand consolidation and mortar crack remediation, HBRC Journal 8 (2012) 185. doi: https://doi.org/10.1016/j.hbrcj.2013.02.001

11. Sharma, A., Ramkrishnan R., Study on effect of microbial induced calcite precipitates on strength of fine grained soils, Perspectives in Science 8 (2016) 198. doi: https://doi.org/10.1016/j.pisc.2016.03.017

12. Arias, D., Cisternas, L. A., Rivas, M., Biomineralization mediated by ureolytic bacteria applied to water treatment: A review, Crystals 7 (2017) 345. doi: https://doi.org/10.3390/cryst7110345

13. Achal, $V$., Pan, $X$., Influence of calcium sources on microbially induced calcium carbonate precipitation by Bacillus sp. CR2, Appl. Biochem. Biotechnol. 173 (2014) 307. doi: https://doi.org/10.1007/s12010-014-0842-1

14. Cheng, L., Shahin, M. A., Cord-Ruwisch, R., Addis, M., Hartanto, T., Elms, C., Soil stabilisation by Microbial-Induced Calcite Precipitation (MICP): Investigation into some physical and environmental aspects, In: Bouazza, A., Yuen, S. T. S., Brown, B. (Eds). $7^{\text {th }}$ International Congress on Environmental Geotechnics: Engineers Australia, 2014, pp. 1105-1112.

15. Balan, S. S., Fazila, F., Jayalakshmi, S., Characterization of urease enzyme from marine bacterium Klebsiella species, Afr. J. Microbiol. Res. 6 (2012) 5914.

16. Cecillia Yappert, M., DuPré, B. D., Complexometric titrations: Competition of complexing agents in the determination of water hardness with EDTA, J. Chem. Educ. 74 (1997) 1421.

17. Castanier, S., Le Métayer-Levrel, G., Orial, G., Loubiere, J. F., Perthuisot, J. P., Bacterial carbonatogenesis and applications to preservation and restoration of historic property, in Ciferri, O., Tiano, P., Mastromei, G. (Eds,), Of microbes and art. The role of microbial communities in the degradation and protection of cultural heritage. Plenum Publisher, New York, 2000, pp 203-218. doi: https://doi.org/10.1007/978-1-4615-4239-1 14

18. Komala, T., Khun, T. C., Calcite-forming bacteria located in limestone area of Malaysia, Journal of Asian Scientific Research 3 (2013) 471.

19. Andersen, A. F., Brecevic, L., Infra-red spectra of amorphous solids and crystalline calcium carbonate, Acta Chem. Scand. 45 (1991) 1018. doi: https://doi.org/10.3891/acta.chem.scand.45-1018

20. Rademaker, H., Launspach, M., Detection of interaction between biomineralising proteins and calcium carbonate micro crystals, Beilstein J. Nanotechnol. 2 (2011) 222. doi: https://doi.org/10.3762/bjnano.2.26

21. de Souza, M. F., Batista, P. S., Regiani, I., Liborio, J. B. L., de Souza, D. P. F., Rice hull-derived silica: Applications in Portland cement and mullite whiskers, Mat. Res. 3 (2000) 25. doi: https://doi.org/10.1590/S1516-14392000000200005

22. Nallathambi, G., Ramachandran, T., Rajendran, V., Palanivelu $R$., Effect of silica nanoparticles and BTCA on physical properties of cotton fabrics, Mat. Res. 14 (2011) 552. doi: https://doi.org/10.1590/S1516-14392011005000086 
23. Chen, L., Shen, Y., Xie, A., Huang, B., Jia, R., Guo, R. Tang, $W$., Bacteria-mediated synthesis of metal carbonate minerals with unusual morphologies and structures, Crys. Growth Des. 9 (2009) 743.

doi: https://doi.org/10.1021/cg800224s

24. Rivadeneyra, M. A., Ramos-Cormenzana, A., Delgado, G., Delgado, R., Process of carbonate precipitation by Deleya halophila, Curr. Microbiol. 32 (1996) 308. doi: https://doi.org/10.1007/s002849900055

25. Hammes, F., Seka, A., De Knijf, S., Verstraete, W., A novel approach to calcium removal from calcium-rich industrial wastewater, Water Res. 37 (2003) 699. doi: https://doi.org/10.1016/S0043-1354(02)00308-1

26. Li, M., Fu, Q. L., Zhang, Q., Achal, V., Kawasaki, S., Biogrout based on microbially induced sand solidification by means of asparaginase activity, Sci. Rep. 5 (2015) 1. doi: https://doi.org/10.1038/srep16128
27. Kang, C. H., Han, S. H., Shin, Y. J., Oh, S. J., So, J. S., Bioremediation of $\mathrm{Cd}$ by microbially induced calcite precipitation, Appl. Biochem. Biotechnol. 172 (2014) 1929. doi: https://doi.org/10.1007/s12010-013-0626-z

28. Dhami, N. K., Reddy, M. S., Mukherjee, A., Biomineralization of calcium carbonate polymorphs by the bacterial strains isolated from calcareous sites, J. Microbiol. Biotechnol. 23 (2013b) 707.

doi: https://doi.org/10.4014/jmb.1212.11087

29. Dhami, N. K., Reddy, M. S., Mukherjee, A., Synergistic role of bacterial urease and carbonic anhydrase in carbonate mineralization, Appl. Biochem. Biotechnol. 172 (2014) 2552.

doi: https://doi.org/10.1007/s12010-013-0694-0 